\title{
Correction to: Scaling Laws of Paleoindian Projectile Point Design
}

\author{
Briggs Buchanan ${ }^{1} \cdot$ Marcus J. Hamilton ${ }^{2}$ \\ Published online: 17 August 2020 \\ (C) Springer Science+Business Media, LLC, part of Springer Nature 2020
}

\section{Correction to: Journal of Archaeological Method and Theory (2020) https://doi.org/10.1007/s10816-020-09481-8}

Due to typesetting mistake, the correction to the formulas at the bottom of page 12 in H2 and H3 were overlooked. Also, Table 2 footnote was incorrectly presented. The original version has been corrected.

Publisher's Note Springer Nature remains neutral with regard to jurisdictional claims in published maps and institutional affiliations.

The online version of the original article can be found at https://doi.org/10.1007/s10816-020-09481-8

Briggs Buchanan

briggs-buchanan@utulsa.edu

$\triangle$ Marcus J. Hamilton

marcus.hamilton@utsa.edu

1 Department of Anthropology, University of Tulsa, Tulsa, OK, USA

2 Department of Anthropology, University of Texas at San Antonio, San Antonio, TX, USA 